\title{
Wind Power Generator Embodied Energy Payback Analysis for Rural Area in Paraná-Brazil
}

\author{
Amauri Ghellere Garcia Miranda ${ }^{1}$, Samuel Nelson Melegari de Souza ${ }^{1}$, Jair Antonio Cruz Siqueira ${ }^{1}$, \\ Luciene Kazue Tokura ${ }^{1}$, Natalia Pereira ${ }^{2}$, Reginaldo Ferreira Santos ${ }^{1}$, Reinaldo Prandini Ricieri ${ }^{1}$, \\ Bruna Pereira da Silva ${ }^{3}$, Lucas Lourenço Corrêa ${ }^{1}$, Abel Alves de Souza ${ }^{1}$, Benhurt Gongora ${ }^{1}$, \\ Fernando Luiz da Cruz Belana ${ }^{1}$, Leonardo da Silva Reis ${ }^{1} \&$ Ricardo Muller ${ }^{4}$ \\ ${ }^{1}$ Department of Energy Engeneering in Agriculture, University of Western Paraná, Cascavel, Paraná, Brazil \\ ${ }^{2}$ Department of Agricultural Engeneering, University of Western Paraná, Cascavel, Paraná, Brazil \\ ${ }^{3}$ Department of Civil Engineering, Paranaense University, Cascavel, Paraná, Brazil \\ ${ }^{4}$ United Nations Industrial Development Organization \& CiBiogas, Foz do Igualu, Paraná, Brazil \\ Correspondence: Natalia Pereira, University of Western Paraná, Cascavel, Universitária St, 2069, 85819-110, \\ Paraná, Brazil. Tel: 55-453-220-3000. E-mail: pe.nataliaa@gmail.com \\ Correspondence Amauri Ghellere Garcia Miranda, University of Western Paraná, Cascavel, Universitária St, \\ 2069, 85819-110, Paraná, Brazil. Tel: 55-459-9993-0564. E-mail: eng.amauri.miranda@gmail.com
}

Received: February 1, 2019

doi:10.5539/jas.v11n6p437
Accepted: March 26, 2019 Online Published: May 15, 2019

URL: https://doi.org/10.5539/jas.v11n6p437

\begin{abstract}
Over the last decades, wind energy has been named as a clean method to generate electrical power. But, to claim this argument many aspects must be evaluated. On one hand, wind power, as an electrical energy source, generates minimum environmental impact when in operation. On the other side, the material extraction for the manufacturing process does create environmental impact and require electrical energy usage. Therefore, when claiming the sustainability of wind power, as a method of electrical power generation, many aspects must be evaluated, such as the Life Cycle Analysis of the turbine. This study has been taken to evaluate the energy cost and its payback period off the wind power turbine S-600, manufactured by Greatwatt, has being evaluated. This evaluation has covered the embodied energy in the gross material present on the final product and its energetic payback period, for the specific case of working in a rural area in the state of Paraná, Brazil. The ISO 14040 methodology, for life cycle analyses, has being applied to estimate the embodied energy in the gross material present on the generator. The annual average energetic production estimation has considered 4 cases, varying the voltage output and hub height, and the nominal capacity, claimed by the manufacturing company. To assess the embodied energy payback period, the theoretical generation capacity has been estimated. Thus, by this analysis, this article has concluded that the embodied energy in the gross material is $803.39 \mathrm{MJ}$. The energetic payback period for this product, at 10 meters hub height, is 11.6 months, if operating on $12 \mathrm{~V}$, and 12.6 months, if operation on $24 \mathrm{~V}$. Furthermore, in the situation of installed at 30 meters from the ground, the energy payback period drops down to 5.3 and 5.5 months, operating on 12 or $24 \mathrm{~V}$ respectively. In the situation of nominal generation, the energetic payback period would dropdown to 4.6 and 3.1 months, operating on 12 or $24 \mathrm{~V}$ respectively.
\end{abstract}

Keyworks: gross material assessment, eolic energy, renewable, life cycle assessment

\section{Introduction}

The search for alternative means of energy generation is increasing in developed and emerging countries. In Brazil, still many rural and remote sites out of the energetic distribution grid. To mitigate this issue, alternatives methods to generate electrical power are being applied (Luis Ferreira et al., 2018; Pallant, Pryputniewicz, \& Lee, 2017).

Worldwide, there are an increasing number of articles being written on the field of renewable energy, and on the subject of Life Cycle Analysis (LCA) the trend isn't different (Schober et al., 2018). In Brazil there are still areas that are not supplied with electricity, according to the National Electric Energy Agency (ANEEL, 2017) about 1 million of Brazilians still live without electricity. In addition, government incentives for the generation of wind 
power have been growing in recent years, creating a positive scenario for this branch (Energy Research Company, 2017).

The energy demand historically grows with the population increase; energy generation capacity must scale in a similar or superior pace. When the generation capacity is lower than the energy demand, the nation faces an energy crisis. It happens when the energetic supply is inferior to the energetic demand. In this case, companies that administrate the distribution greed end up with sites without electrical energy, that can lead to animal death and production reduction in rural areas (Chaurey et al., 2004; Ellman, 2015)

Some field of farming relays directly on energy supply to sustain its process, such as chicken production. Animal death can happen if electrical energy cannot be delivered (WSPA, 2014). In this case, Heat and Ventilation Air Conditioning (HVAC) systems, light and water and food distribution are driven by electrical power. With the technological evolution in the chicken farming process, the time period has dropped down significantly over the last decades (Ledur et al., 2011). Unfortunately, this evolution has leaded to a very sensitive situation, where electrical energy interruption is not tolerated.

The use of wind power as an alternative to on-site generation is an option with great potential. With this technology and power bank systems electrical energy distribution assurance can be fortified. However, looking for a sustainable future, efficiency in the production of power generators must be evaluated.

A usual approach for this evaluation is the Life Cycle Analysis, LCA. It can take many segments, depending on the focus of this study. The LCA of a wind power generator can be driven to estimate the embodied energy present in some specific product (Goulart Coelho \& Lange, 2018). In addition of this data, LCA can be applied with the annual energetic generation capacity of the turbine to estimate, what is called, the Energetic Payback Period. It is, the time span needed to this generator produce as much energy as implied in its parts.

To estimate the energetic payback period of the wind turbine, the power generation capacity of the generator should be evaluated. By conferring aspects inherent to its, concept of manufacturing, conditions of application and environmental conditions of the place, instantaneous generation of energy and, consequently, the average generation capacity can be estimated (Tremeac \& Meunier, 2009).

The principle of operation of wind generators performs the following task: they convert energy available in the winds in mechanical energy, which in turn can be converted into electric energy (Energy. Gov., 2014). In a life cycle analysis, data relating to the mechanical construction material used in the product and its mass must be quantified to determine the energy built into this component (Guinée, 2002).

And, to enable the presence of the embodied energy of a particular product bibliographical survey sources can be used to define equivalent energy by material. In this way, knowing the materials applied in the product and its respective mass, it's possible to calculate the total amount of embodied energy of this component (Chau et al., 2015).

In this scenario, wind power generation is one option and this article has been leaded to evaluate the real capacity and yield of this method. The objective of this study was, to calculate the embodied energy present on the material of the S-600 Greatwatt ${ }^{\circledR}$ wind power turbine and its payback period. To do so: First, the equivalent energy per kilogram of material, respectively, has being calculate; after, the generation capacity of the turbine, when operation in the place where the study has taken place, was estimated. Finally, the payback period has being calculated.

\section{Material and Methods}

\subsection{Characterization of the Place of Study and of the Generator}

The survey was carried out on the Cascavel Campus of the State University of West Paraná, the Paraná, Brazil, with coordinates $24^{\circ} 59^{\prime} 21.908^{\prime \prime} \mathrm{S}, 5^{\circ} 26^{\prime} 59.291^{\prime \prime} \mathrm{W}$ (Google Inc., 2018; Parizotto et al., 2014). According to the climatic classification of Köppen-Geiger, Rattlesnake is located in the Cfa climate region, with temperatures below $18{ }^{\circ} \mathrm{C}$ and warm summers with temperatures above $22^{\circ} \mathrm{C}$.

The meteorological conditions analyzed were provided by the Paraná Meteorological System (Simepar) and collected at the meteorological station of the city of Cascara, Paraná, Brazil. This station is located 719 meters above sea level (Gonçalves, 2007).

The interval between the data acquisition was 1 hour in a period spanning 10 years. The collections took place between 16/10/2007, 00:00 hours, the 17/10/2017 09:00. Which measured the following parameters: Wind speed $(\mathrm{m} / \mathrm{s})$, atmospheric pressure $(\mathrm{hPa})$, wind direction $\left(0^{\circ}, 45^{\circ}, 90^{\circ}, 135^{\circ}, 180^{\circ}, 225^{\circ}, 270^{\circ}\right.$ or $\left.315^{\circ}\right)$, relative humidity $(0-100 \%)$ and temperature $\left({ }^{\circ} \mathrm{C}\right)$. 


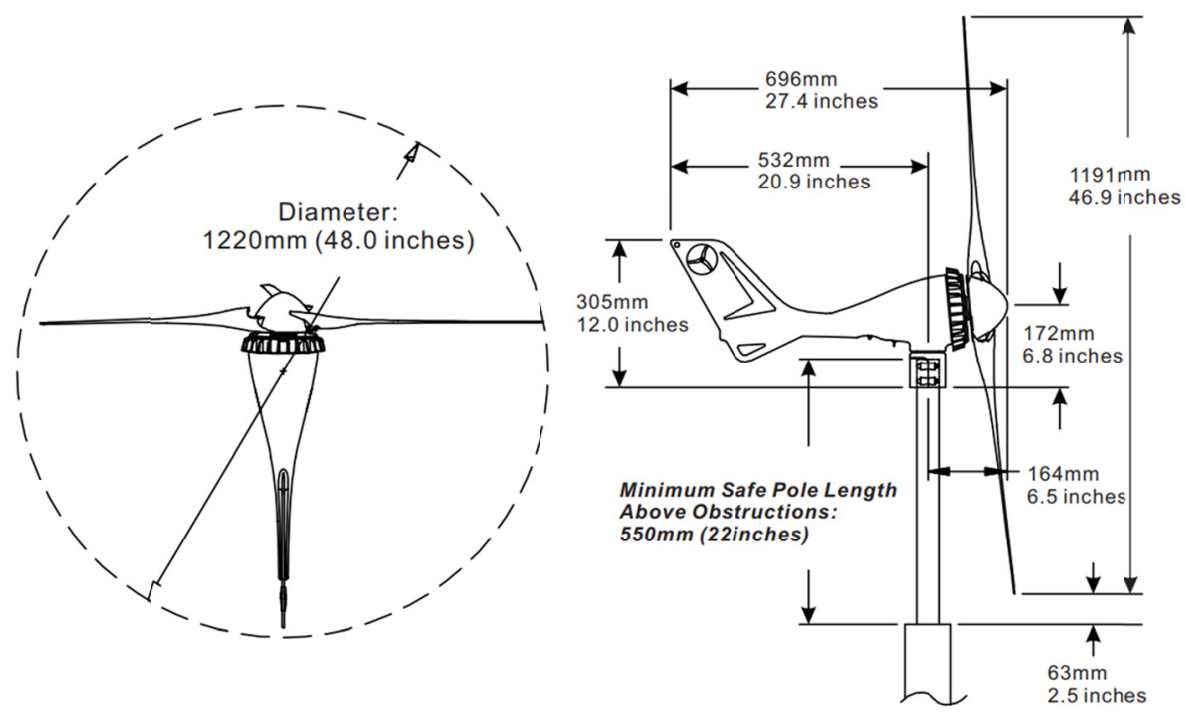

Figure 1. Dimensions of the wind turbine

Source: Greatwatt Energy (n.d.).

It has been used a Greatwatt S-600 model wind turbine (Figure 1) with the following technical specifications (Table 1).

Table 1. Technical specifications of wind turbine Greatwatt S-600

\begin{tabular}{|c|c|c|}
\hline Configuration & \multicolumn{2}{|c|}{3 blades, upwind } \\
\hline Rotor Diameter & \multicolumn{2}{|c|}{$1.191 \mathrm{~m}$ (46.9 in) } \\
\hline Net Weight & \multicolumn{2}{|c|}{$6.3 \mathrm{~kg}$ (13.9 lb.) } \\
\hline High-speed Control & \multicolumn{2}{|c|}{ Hysteresis Braking (slowdown) } \\
\hline Over-speed Protection & \multicolumn{2}{|c|}{ Hysteresis Braking (slowdown) } \\
\hline \multirow[t]{2}{*}{ Electrical Voltage } & \multicolumn{2}{|c|}{ DC 12 V/DC $24 \mathrm{~V}$ (Voltage Smart Change) } \\
\hline & $12 \mathrm{~V}$ & $24 \mathrm{~V}$ \\
\hline Rated Power & $400 \mathrm{~W}$ & $600 \mathrm{~W}$ \\
\hline Max Power & $550 \mathrm{~W}$ & $750 \mathrm{~W}$ \\
\hline Startup wind speed & \multicolumn{2}{|c|}{$3 \mathrm{~m} / \mathrm{s}(6.7 \mathrm{mph})$} \\
\hline Start Charging wind speed & \multicolumn{2}{|c|}{$2.5 \mathrm{~m} / \mathrm{s}(5.6 \mathrm{mph})$} \\
\hline Rated wind speed & \multicolumn{2}{|c|}{$12.5 \mathrm{~m} / \mathrm{s}(28 \mathrm{mph})$} \\
\hline Incision wind speed & \multicolumn{2}{|c|}{$25 \mathrm{~m} / \mathrm{s}(56 \mathrm{mph})$} \\
\hline Survival wind speed & \multicolumn{2}{|c|}{$60 \mathrm{~m} / \mathrm{s}(134 \mathrm{mph})$} \\
\hline
\end{tabular}

Note. Information on Table 1 extracted from the wind turbine manual provided by the factory (Greatwatt Energy, n.d.).

\subsection{Quantification of Embedded Energy}

The methodology to calculate the embodied energy in the material present on the turbine the following steps can be followed: bibliography regarding equivalent embodied energy per kilogram of gross material; weighting process of parts and dissembling

The embodied materials quantification of a wind turbine was be made through the process of disassembling and weighing all the pieces. Once knowing and cataloging all the materials and its respective mass present in the analyzed product, the quantification of inline power can take base. Therefore, in this phase bibliographic database, displayed in the Table 2, can be applied to estimate the embodied energy and the mass of carbon dioxide equivalent of the wind energy turbine. 
Guinée (2002) presents in its study the equation for quantifying the embodied energy. This uses the mass quantity of each material applied in the evaluated product. The total amount of the built-in energy was determined by applying the following Equation 1 .

$$
\mathrm{EE}_{\mathrm{m}_{\mathrm{i}}}=\left(\sum \mathrm{m}_{\mathrm{m}_{\mathrm{i}}}\right) \times \mathrm{EEI}_{\mathrm{m}_{\mathrm{i}}}
$$

Where, $\mathrm{EE}_{\mathrm{m}_{\mathrm{i}}}=$ built-in energy for certain material (MJ); $\mathrm{m}_{\mathrm{m}_{\mathrm{i}}}=$ mass of the material in each component $(\mathrm{kg})$; $\mathrm{EEI}_{\mathrm{m}_{\mathrm{i}}}=$ Energy built-in material $(\mathrm{MJ} / \mathrm{kg})$.

This way the equivalent energy is obtained for each material in the final product. And the total equivalent energy, given in MJ, of the evaluated subject is found by the sum of all energy equivalents by material (Equation 2) (Finkbeiner et al., 2006).

$$
\mathrm{EE}=\sum \mathrm{EE}_{\mathrm{m}_{\mathrm{i}}}
$$

Table 2. Inline equivalent embodied energy for material present in the Greatwatt wind turbine model S-600

\begin{tabular}{ll}
\hline Material & Built-in energy equivalent $(\mathrm{MJ} / \mathrm{kg})$ \\
\hline Aluminum & 464.36 \\
Copper & 104.29 \\
Steel & 37.10 \\
CFRP & 143.30 \\
Neodymium & 47.10 \\
Polymer & 6.27 \\
Rubber & 0.87 \\
Iron & 0.10 \\
\hline Total & $\mathbf{8 0 3 . 3 8}$ \\
\hline
\end{tabular}

Note. Adopted values of: ${ }^{1,7}$ Melconian (2012); ${ }^{2}$ Moro and Auras (2007); ${ }^{3,4}$ Greatwatt Energy (n.d.); ${ }^{5,6}$ Oliveira (2009); ${ }^{8}$ Bai et al. (2013); Song, Youn, and Gutowski (2009).

\subsection{Energy Return}

The evaluation of the energy return of the implantation followed the following guidelines: survey of meteorological data. The meteorological data obtained shows information about wind speed, temperature, fluid-specific mass and wind direction at each particular collection interval.

Subsequently, with this data, previously described, in hand; Prior treatment was carried out (pre-processing of data and calculations). In this instance all the values provided by Simepar were introduced in the Windographer ${ }^{\circledR}$ software and system functions were used with the scope of verifying possible fictitious data, such as negative velocity or exorbitant winds, periods without Data collection or any erroneous information that would disqualify the final analysis (Linard, 2010).

It was used the meteorological information, which was inserted in the software along with information regarding the nominal power generation capacity of the generator worked. At this stage the software performed equations of power generation capacity for each collection interval, taking into consideration the generator to be studied and the altitude of its installation. In this way, one can quantify the power generation capacity of the generator in operation at that instant (Balakrishna et al., 2017).

The energy generation capacity of the turbine was calculated using real local meteorological data. In addition, tree scenarios were created. First, the nominal generation capacity of the wind power generator, N12 and N24, operating at $12 \mathrm{~V}$ and $24 \mathrm{~V}$ respectively, was calculated. Second, analyzing the installation of the product 10 meters elevation from the ground level, 10_12 and 10_24. Third, the installation possibility of installation at 30 meters elevation from the ground level, 30_12 and 30_24.

\subsection{Energy Payback}

The payback is about the time taken for the investment to be paid (Al-Ani, 2015). The time of energy payback of the generator took into consideration: generating capacity of the generator when in operation and 12 and $24 \mathrm{~V}$, climatic conditions and energy cost embedded in the materials employed in the model. This energy cost was calculated by analyzing the mass of each component and its specific energy cost, as to its material. 
The payback, then, given in months, it was quantified by the equation of Peharz and Dimroth (2005) (Equation 3):

$$
\mathrm{TPE}=\mathrm{EE} /\left(\mathrm{E} \_\mathrm{p}+\mathrm{E} \_\mathrm{g}\right) \mathrm{R}
$$

where, TPE = Time of energy Payback (years); EE = inbuilt energy (MJ); E_p = energy produced in one year of generation $\left(\mathrm{KWh} /\right.$ year); $\mathrm{E} \_\mathrm{g}=$ energy spent during production in one year of generation $(\mathrm{kwh} / \mathrm{year})$ and $\mathrm{R}$ $=\mathrm{kwh}$ conversion factor for MJ (3.6 MJ/kWh) (Manwell et al., 2010).

\section{Results and Discussion}

\subsection{Quantification of Embedded Energy and Environmental Impact on Energy Generation}

Once the mass of each material has been verified in the composite components and the mass of the other components has been raised in the weighing process, the total mass amount for each material has been found (Table 3). The most representative material is aluminum, participating with $49.70 \%$ of the total mass. Following is copper, $22.30 \%$, steel, $15.37 \%$, CFRP, $9.13 \%$, neodymium, $2.09 \%$, rubber, $0.17 \%$, and iron, $0.07 \%$.

Table 3. Mass by material found in the Greatwatt model S-600 and its respective participation in the total mass

\begin{tabular}{lll}
\hline Material & Total weight $(\mathrm{g})$ & $\%$ of total \\
\hline Aluminum & 2978.74 & $49.70 \%$ \\
Cooper & 1336.87 & $22.30 \%$ \\
Steel & 919.25 & $15.34 \%$ \\
CFRP & 547.46 & $9.13 \%$ \\
Neodymium & 125.17 & $2.09 \%$ \\
Polymer & 72.14 & $1.20 \%$ \\
Rubber & 10.22 & $0.17 \%$ \\
Irron & 4.03 & $0.07 \%$ \\
Total & $\mathbf{5 9 9 3 . 8 8}$ & $\mathbf{1 0 0 . 0 0 \%}$
\end{tabular}

Note. Value extract of: weighing process of each part of the S-600 Greatwatt wind power generator.

It has also been observed that aluminum is the most significant material as much as mass-sensing material in the generator as in the impact of built-in energy. Although aluminum is a light material, it has a large energy consumption per unit weight (Venkatarama Reddy \& Jagadish, 2003; Savino et al., 2017).

Despite Neodymium relative mass be only $2.09 \%$, percentage of total mass, it impacts on the wind turbine energetic cost with an amount greater than copper, material with second largest representative mass in the generator. The energy cost of iron, rubber, polymer and neodymium added account for only $3.53 \%$ of the total.

The value used to calculate the total embodied energy of the product in this study was the average value found in literature. The full list of authors and its respective equivalent embodied energy for each gross material is presented in the Table 4. 
Table 4. Equivalent embodied energy per mass of gross material $(\mathrm{MJ} / \mathrm{kg})$

\begin{tabular}{|c|c|c|c|c|c|c|c|c|}
\hline Steel & Aluminum & Rubber & CFRP & Cooper & Neodymium & Iron & Polymer & Reference \\
\hline \multirow[t]{3}{*}{32.00} & & & & & & & & (Alcorn \& Baird, 1996; González \& García Navarro, 2006) \\
\hline & & 95.00 & & & & & & (Allen \& Iano, 2013) \\
\hline & & & & & & & 72.40 & (Andrady, 2003) \\
\hline 45.70 & 157.10 & & & 69.00 & 31.30 & 24.30 & & (Benton, 2016) \\
\hline 51.50 & 231.00 & 88.00 & & 140.00 & & 32.70 & 52.50 & (Boustead \& Hancock, 1979) \\
\hline \multirow[t]{2}{*}{21.80} & 95.90 & & & & & & & (BrasiL, 1982) \\
\hline & & & 344.00 & & & & & (Das, 2011) \\
\hline \multirow[t]{2}{*}{17.90} & 34.80 & & & 14.90 & & 6.00 & 12.70 & (Fleck \& Huot, 2009) \\
\hline & & & & & 158.00 & & & (Frischknecht et al., 2007) \\
\hline 25.60 & & & & & & & & (Guimarães, 1985) \\
\hline \multirow[t]{3}{*}{160.00} & 226.50 & & 234.50 & & & & 70.50 & (Howarth, Mareddy, \& Mativenga, 2014) \\
\hline & 145.00 & & & 110.00 & & 40.00 & 105.00 & (Khan, Hawboldt, \& Iqbal, 2005) \\
\hline & & & 234,00 & & & & & (Kim, Advisor, \& Enemuoh, 2014) \\
\hline 33.70 & & & & & & & & (Lee, Trcka, \& Hensen, 2011) \\
\hline 51.50 & 231.00 & 88.00 & & 140.00 & & 32.70 & 110.20 & (Mantoam, 2016) \\
\hline 42.70 & & & & & & & & (Monahan \& Powell, 2011) \\
\hline \multirow[t]{2}{*}{20.10} & 155.00 & & & 42.00 & & 25.00 & & (Butcher, Hammond, \& Jones, 2006) \\
\hline & & 86.00 & & & & & & (Rydh \& Sun, 2005) \\
\hline 10.30 & & & & & & & & (Silva \& Silva, 2015) \\
\hline 18.00 & & 67.50 & 234.50 & 59.00 & & 26.50 & 71.50 & (Schnöll et al., 2015) \\
\hline 30.50 & & & & & & & & (Song, Youn, \& Gutowski, 2009) \\
\hline 30.50 & 210.00 & & & & & & & (Sposto, Caldas, \& Neto, 2016) \\
\hline 54.00 & 72.60 & & & 49.20 & 939.50 & 15.90 & 200.00 & (Tavares \& Lamberts, 2008) \\
\hline 32.00 & & & & & & & & (Wang \& Teah, 2017) \\
\hline 40.4 & 155.9 & 84.9 & 261.8 & 69.3 & 376.3 & 25.4 & 86.8 & Average value \\
\hline 160.00 & 231.00 & 95.00 & 344.00 & 140.00 & 939.50 & 40.00 & 200.00 & Maximum value \\
\hline 10.30 & 34.80 & 67.50 & 234.00 & 0.00 & 31.30 & 6.00 & 12.70 & Minimum value \\
\hline
\end{tabular}

Crossing the data of equivalent mass per material and the equivalent embodied energy per mass of gross material, was possible to calculate the equivalent embodied energy of the product (Al-Behadili et al., 2015). The results were presented in Figure 2.

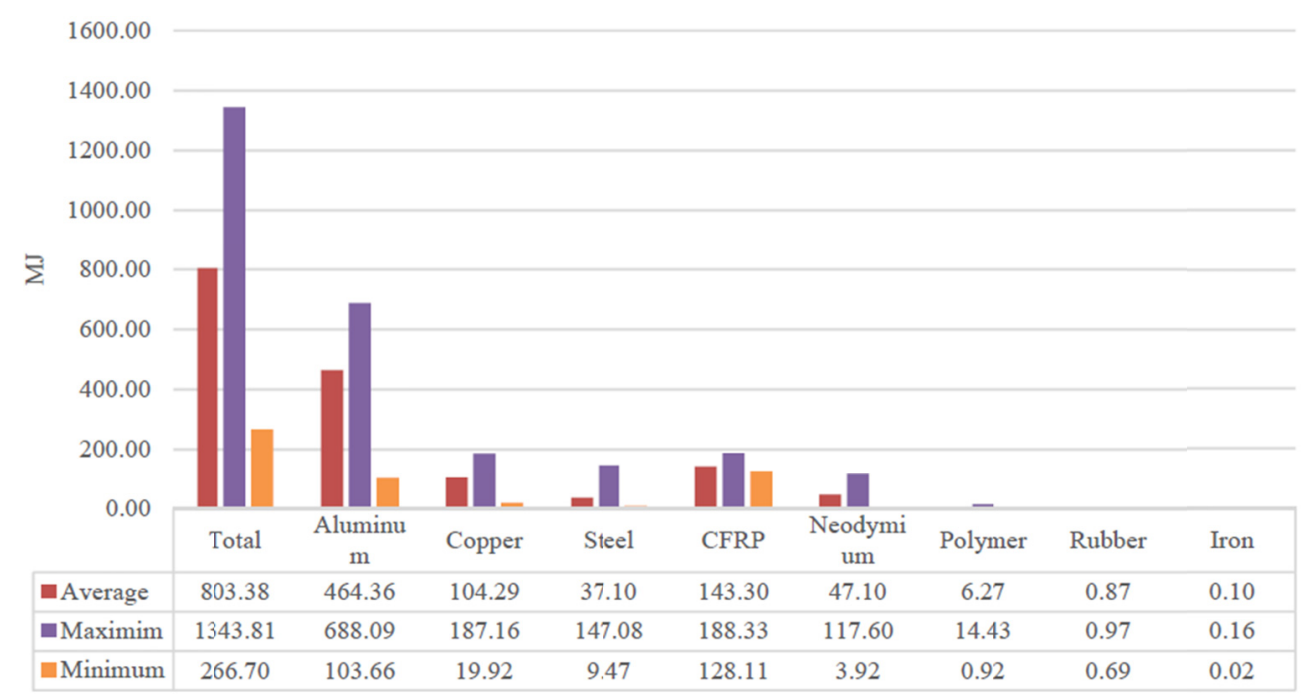

Figure 2. Embodied energy at the Greatwatt S-600 wind power generator

As presented in Figure 2, if utilizing the average value, found in literature, of embodied energy per mass of material, the mass of the materials employed in the generator related to the amount of energy built into each material resulted in an average built-in energy cost of the 803.38 MJ generator. Previous studies show that 
energy built into a generator can range from 3948 MJ into a $500 \mathrm{KW}$ system (Pick \& Wagner, 2002) to 15945 MJ in a 3.0 MW system (Vestas Wind Systems, 2006).

The material that represents the greater amount of respective energy cost is the Aluminum, where its equivalent embodied energy found in this study were 464.62 MJ; followed by CFRP, with 143.30 MJ; Cooper, with 104.29 MJ; Neodymium, with 47.10; Steel, with 37.10 MJ; Polymer, with 6.27 MJ; Rubber, with 0.87 MJ; and, Iron, with 0.10 MJ (Figure 2).

\subsection{Energy Return}

The nominal generation capacity was calculated operating at $12 \mathrm{~V}$ and $24 \mathrm{~V}$ (named N12 and N24), respectively. If this generator was operating full-time in the nominal capacity power generation capacity, it would generate $3504 \mathrm{kWh} /$ year at $12 \mathrm{~V}$ and $5256 \mathrm{kWh} /$ year at $24 \mathrm{~V}$.

The theoretical energy generation capacity for the bub height of 10 meters, when operating at $12 \mathrm{~V}$ output (named 10_12), it is capable to generate $325 \mathrm{kWh} /$ year. And, this generation capacity drops down to 298 $\mathrm{kWh}$ /year when the output voltage was $24 \mathrm{~V}$ (named 10_24) (Table 5).

Table 5. Basic generation data of a wind turbine Greatwatt model S-600

\begin{tabular}{lll}
\hline Turbine & S-600 $(12 \mathrm{~V})(10 \mathrm{~m})$ & S-600 $(24 \mathrm{~V})(10 \mathrm{~m})$ \\
\hline Valid time data $(\%)$ & 4.09 & 4.09 \\
Average wind speed $(\mathrm{m} / \mathrm{s})$ & 30.83 & 30.83 \\
Percentage of time at zero $(\%)$ & 0 & 0.07 \\
Percentage of time at nominal (\%) & 3504 & 5256 \\
Output power $(\mathrm{kW})$ & 386 & 355 \\
\hline Annual generation $(\mathrm{kWh} /$ year) & 1389.6 & 1278 \\
\hline
\end{tabular}

The embodied energy it would generate $1389.6 \mathrm{MJ} /$ year, at the current output of $12 \mathrm{~V}$, and $1278 \mathrm{MJ} /$ year, at $24 \mathrm{~V}$ (Heiwitt, 2015).

Furthermore, contracting the nominal generation capacity and the evaluation of the situation of $10 \mathrm{~m}$ height wind: capacity factor of $11.02 \%$ and $6.75 \%, 12 \mathrm{~V}$ and $24 \mathrm{~V}$ respectively. Independent of the lower current, even at $12 \mathrm{~V}$ the generator would have an annual average generation higher than $24 \mathrm{~V}$.

Since, it was found that the generation capacity of the turbine would be greater wen operating at $12 \mathrm{~V}$ than $24 \mathrm{~V}$ output, when installed at the incase site, opposite situation if compared with the nominal generation capacity, a short analysis was leaded.

The percentage of time that this turbine would be acting the nominal capacity of generation of energy (Table 4). It shows that, if set to operate at $12 \mathrm{~V}$ at no time would it be generating $400 \mathrm{~W}$. On the other hand, with the $24 \mathrm{~V}$ output current setting, only $0.07 \%$ of the time would be generating $600 \mathrm{~W}$. In addition, idle time, where it would not be generating power, of the generators is approximately $30 \%$ of the total time. Leading to the hypothesis of the wind power generator characteristics is not adequate for the wind speed weilbull distribution for this site location. This hypothesis takes place due to the fact that the generation capacity power curve is directly dependent of the wind speed. To deepen its analysis, the hub height variable was changed.

Wind speed varies with the gain of height, in low altitude from the ground and situations applied for wind power. In addition, the hub height variant is a plausible option to be used when looking for evaluates higher wind speed. Because, the height from the ground to the horizontal axes of a wind power generator depends of the size, altitude, of the tower to be installed generation (Manwell et al., 2010).

The 30 meters hub height has been tested leading to greater wind speed average and consequently superior capacity factor. This is due to the wind speed weilbull scenario; therefore, a wind turbine. With the hub height of 30 meters the average calculated wind speed would be $5.79 \mathrm{~m} / \mathrm{s}$, an increase of $41.56 \%$.

For the theoretical situation analyzed of 30 meters hub height, the average energy output for 12 and $24 \mathrm{~V}$, named in this study 30_12 and 30_24 respectively, would be 3028 and $2948 \mathrm{MJ} /$ year. Facing an increase of 217.8\%, for both voltage output. Nevertheless, the generation capacity still greater when operating at $12 \mathrm{~V}$ output.

For each scenario, the annual generation capacity was: $N 12=3504 \mathrm{MJ} /$ year; $N 24=5256 \mathrm{MJ} /$ year; $10 \_12=$ $1390 \mathrm{MJ} /$ year; $10 \_24=1278 \mathrm{MJ} /$ year; 30_12=3028MJ/year; and 30_24 $=2948 \mathrm{MJ} /$ year. 


\subsection{Energy Payback}

It was verified that the total energetic cost of the aero generator is of $803.38 \mathrm{MJ}(223.16 \mathrm{kWh})$, considering the average information found for mega Joule per kilogram for the materials. Thus, the payback time of the wind turbine in operation generating $12 \mathrm{~V}$ and $24 \mathrm{~V}$ current would be 11 months 18 days and 3 hours and 1 year 18 days and 13 hours, respectively (Figure 3 ).

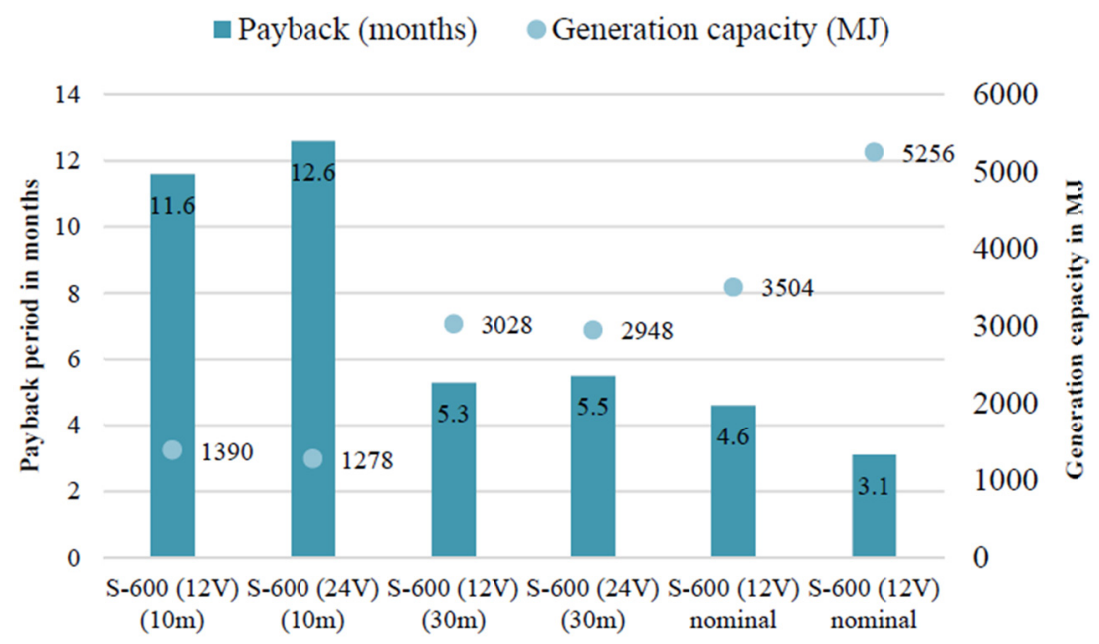

Figure 3. Energy payback period of a Greatwatt S-600 wind turbine

When analyzing the panorama of the installation of the aero generator with a current of 30 meters the results referring to the generation capacity are more satisfactory, regarding its generation capacity. Consequently, the energy payback time is reduced, compared to the tower of only 10 meters. In this situation the energy payback time for the $12 \mathrm{~V}$ generation configurations is 5 months 9 days and 18 hours, having a $46 \%$ reduction in the final energy payback time.

When taking the maximum values for the equivalent embodied energy per kilogram of material, as found in literature, the total embodied energy is 1343.81 MJ. This evaluation has taken place to analyses the worst case, assuming the situation off the maximum impact. Where, in this case, value $167.27 \%$ greater than the average value calculated for the average data found.

Also, the minimum value was utilized to verify the energetic cost of the wind turbine. This have the goal to assess the situation were the lowest energetic cost per gross material, as found in literature, is the case. In this calculation, was found that the energetic cost of the turbine is $226.70 \mathrm{MJ}, 33.20 \%$ of the amount found using the average value and $19.85 \%$ when using the maximum value.

\section{Conclusions}

The total mass of the wind power generator is 5993.88 grams. Aluminum was the most representative material with $2978.74 \mathrm{~g}$; followed by cooper, with $1336.87 \mathrm{~g}$; steel, with $919.28 \mathrm{~g}$; neodymium, with $125.17 \mathrm{~g}$; polymer, with $72.14 \mathrm{~g}$; rubber, with $10.22 \mathrm{~g}$; and iron, $4.03 \mathrm{~g}$.

By the LCA the energy embedded in the evaluated product was $803.38 \mathrm{MJ}$ and the energy payback time was 11 months and 18 days, when generating energy at $12 \mathrm{~V}$, and 1 year and 18 days, at $24 \mathrm{~V}$. The energy return of the turbine studied was $1390.6 \mathrm{MJ} /$ year (12 V) and $1278 \mathrm{MJ} /$ year (24 V).

The height of the hub in the assembly of the aerogenerator presented favorable and considerable results for the studied site.

\section{References}

Al-Ani, M. K. (2015). A strategic framework to use payback period (PBP) in evaluating the capital budgeting in energy and oil and gas sectors in Oman. International Journal of Economics and Financial Issues, 5(2), $469-475$. 
Al-Behadili, H., Grumpe, A., Dopp, C., \& Wohler, C. (2015). Extreme Learning Machine based Novelty Detection for Incremental Semi-Supervised Learning. International Conference on Image Information Processing (pp. 230-235). https://doi.org/10.1109/ICIIP.2015.7414771

Alcorn, J. A., \& Baird, G. (1996) Use of a hybrid energy analysis method for evaluating the embodied energy of building materials. Renewable Energy, 8(1), 319-322. https://doi.org/10.1016/0960-1481(96)88869-0

Allen, E., \& Iano, J. (2013). Fundamentos da Engenharia de Edificações-Materiais e Métodos (5th ed.). Porto Alegre: Bookman.

Andrady, A. L. (2003). Plastics and the Environment. New Jersey: John Wiley \& Sons. https://doi.org/10.1002/ 0471721557

ANEEL. (2017). Capacidade de Geração do Brasil. Retrieved from http://www2.aneel.gov.br/aplicacoes/ capacidadebrasil/capacidadebrasil.cfm

Bai, C. J., Hsiao F. B., Li, M. H., Huang, G. Y., \& Chen, Y. J. (2013). Design of 10 kW Horizontal-Axis Wind Turbine (HAWT) Blade and Aerodynamic Investigation Using Numerical Simulation. Procedia Engineering, 67, 279-287. https://doi.org/10.1016/j.proeng.2013.12.027

Balakrishna Moorthy, C., Balasubramanian, C., \& Deshmukh, M. K. (2017). Wind Turbine Output Estimation using Windographer Software. International Journal on Future Revolution in Computer Science \& Communication Engineering, 3(11), 2454-4248.

Benton, K. (2016). A life cycle assessment of a diesel generator set (Graduate Theses \& Non-theses, 63, Montana Tech of The University of Montana). Retrieved from https://digitalcommons.mtech.edu/ cgi/viewcontent.cgi?article $=1065 \&$ context $=$ grad_rsch

Boustead, I., \& Hancock, G. F. (1979). Handbook of industrial energy analysis. New York: John Wiley \& Sons. https://doi.org/10.1002/aic.690260138

Brasil. (1982). Balanço energético de edificações típicas. Brasília: Ministério da Indústria e Comércio, Secretaria de Tecnologia Industrial-Fundação Centro Tecnológico de Minas Gerais-CETEC/MG.

Butcher, O. M., Hammond, G. P., \& Jones, C. I. (2006). Technological Potential for Zero or Low Carbon (ZLC)_Energy Options in the UK Building Sector (pp 21-28). The 2nd Joint International Conference on Sustainable Energy and Environment, Bangkok, Thailand.

Chau, C. K., Leung, T. M., \& Ng, W. Y. (2015). A review on life cycle assessment, life cycle energy assessment and life cycle carbon emissions assessment on buildings. Applied Energy, 143, 395-413. https://doi.org/ 10.1016/j.apenergy.2015.01.023

Chaurey, A., Ranganathan, M., \& Mohanty, P. (2004). Electricity access for geographically disadvantaged rural communities-Technology and policy insights. Energy Policy, 32, 1693-1705. https://oi.org/10.1016/ S0301-4215(03)00160-5

Crawford, R. H. (2005). Validation of the Use of Input-Output Data for Embodied Energy Analysis of the Australian Construction Industry. Journal of Construction Research, 6, 71-90. https://doi.org/10.1142/ S1609945105000250

Das, S. (2011). Life cycle assessment of carbon fiber-reinforced polymer composites. The International Journal of Life Cycle Assessment, 16(3), 268-282. https://doi.org/10.1007/s11367-011-0264-z

Ellman, D. (2015). The reference electrification model: A computer model for planning rural electricity access (Thesis, S.M. in Technology and Policy, Massachusetts Institute of Technology, Engineering Systems Division).

Energy Research Company. (2017). 2017 Statistical yearbook of electricity. Ministério de Minas e Energia. Retrieved from http://www.epe.gov.br

Energy. Gov. Office of Energy Efficiency \& Renewable Energy. Retrieved from http://energy.gov/eere/wind/ how-do-wind-turbines-work

Finkbeiner, M., Inaba, A., Tan, R., Christiansen, K., \& Klüppel, H. (2006). The New International Standards for Life Cycle Assessment: ISO 14040 and ISO 14044. The International Journal of Life Cycle Assessment, 11(2), 80-85. https://doi.org/10.1065/lca2006.02.002

Fleck, B., \& Huot, M. (2009). Comparative life-cycle assessment of a small wind turbine for residential off-grid use. Renewable Energy, 34(12), 2688-2696. https://doi.org/10.1016/j.renene.2009.06.016 
Frischknecht, R., Jungbluth, N., Althaus, H.-J., Bauer, C., Doka, G., Dones, R., ... Nemecek T. (2007) Implementation of Life Cycle Impact Assessment Methods (Ecoinvent Report 3, p. 2). Swiss Centre for Life Cycle Inventories, Dübendorf. Retrieved from https://inis.iaea.org/collection/NCLCollectionStore/_Public/ 41/028/41028089.pdf? $r=1 \& r=1$

Ghenai, C. (2012). Life Cycle Analysis of Wind Turbine, Sustainable Development. In C. Ghenai (Ed.), Energy, Engineering and Technologies - Manufacturing and Environment. London: InTech. https://doi.org/10.5772/ 29184

Gonçalves, R. C. (2007). Análise de Frequência Regional de Ventos Extremos no Paraná (p. 206, Master's thesis, Universidade Federal do Paraná, Setor de Tecnologia, Programa de Pós-Graduação em Engenharia de Recursos Hídricos e Ambiental). Retrieved from http://hdl.handle.net/1884/11160

González, M. J., \& García Navarro, J. (2006). Assessment of the decrease of $\mathrm{CO}_{2}$ emissions in the construction field through the selection of materials: Practical case study of three houses of low environmental impact. Building and Environment, 41(7), 902-909. https://doi.org/10.1016/j.buildenv.2005.04.006

Google Inc. (2018). Google Maps. Retrieved from https://goo.gl/maps/oJ6ilkJw42k

Goulart Coelho, L. M., \& Lange, L. C. (2018). Applying life cycle assessment to support environmentally sustainable waste management strategies in Brazil. Resources, Conservation and Recycling, 128, 438-450. https://doi.org/10.1016/j.resconrec.2016.09.026

Greatwatt Energy. (n.d.). L. S-600 Wind Generator Serial Number. Suzhou, China.

Guimarães, G. D. (1985). Análise energética na construção de habitações (Masters thesis, Programa de Pós-Graduação em Planejamento Energético, COPPE, Universidade Federal do Rio de Janeiro).

Guinée, J. B. (2002). Handbook on life cycle assessment: Operational guide to the ISO standards. Netherlands: Springer. https://doi.org/10.1007/BF02978897

Heiwitt, P. (2015). Física Conceitual (12th ed.). Porto Alegre: Bookman.

Howarth, J., Mareddy, S. S. R., \& Mativenga, P. T. (2014). Energy intensity and environmental analysis of mechanical recycling of carbon fibre composite. Journal of Cleaner Production, 81, 46-50. https://doi.org/ 10.1016/j.jclepro.2014.06.023

Jurach, J. J. (2004). Influência do tamanho e forma na qualidade das sementes de milho durante armazenagem (Master's thesis, Universidade Estadual do Oeste do Paraná). Retrieved from http://tede.unioeste.br/handle/ tede/1374

Khan, F. I., Hawboldt, K., \& Iqbal, M. T. T. (2005). Life Cycle Analysis of wind-fuel cell integrated system. Renewable Energy, 30(2), 157-177. https://doi.org/10.1016/j.renene.2004.05.009

Kim, S., Advisor, F., \& Enemuoh, E. (2014). Engineering Sustainability of Mechanical Recycling of Carbon Fiber Composite Materials. Retrieved from http://hdl.handle.net/11299/168168

Ledur, M. C., Figueiredo, E. A. P., Schmidt, G. S., Avila, V. S., \& Peixoto, J. O. (2011). O melhoramento genético de aves no Brasil e as contribuições da Embrapa Suínos e Aves. In J. C. P. V. B. Souza, D. J. D. Talamini, G. N. Scheuermann, \& G. S. Schmidt (Eds.), Sonho, desafio e tecnologia: 35 anos de contribuições da Embrapa Suínos e Aves. Concórdia: Embrapa Suínos e Aves. Retrieved from https://www.embrapa.br/documents/1355242/0/Aves+-+cap\%C3\%ADtulo+11.pdf. 2011

Lee, B., Trcka, M., \& Hensen, J. L. M. (2011). Embodied energy of building materials and green building rating systems-A case study for industrial halls. Sustainable Cities and Society, 1(2), 67-71. https://doi.org/ 10.1016/j.scs.2011.02.002

Linard, F. J. A., \& Silva, E. M. (2010). Uso do software Windographer ${ }^{\circledR}$ para estimativas da velocidade do vento em altitude numa região do litoral cearense. Congresso Brasileiro de Meteorologia. Belém do Pára, Brazil.

Mantoam, E. J., \& Romanelli, T. L. (2016). Inventário de materiais, energia e emissões dos gases de efeito estufa na vida útil de máquinas agrícolas (Master thesis, Universidade de São Paulo, Piracicaba). Retrieved from http://www.teses.usp.br/teses/disponiveis/11/11152/tde-09082016-165014/

Manwell, J. F., McGowan, J. G., \& Rogers, A. L. (2010). Wind energy explained: Theory, design and application. Canada: Willey. https://doi.org/10.1002/9781119994367.app2 
Martínez, E., Sanz, F., Pellegrini, S., Jiménez, E., \& Blanco, J. (2009). Life cycle assessment of a multi-megawatt wind turbine. Renewable Energy, 34(3), 667-673. https://doi.org/10.1016/j.renene.2008.05. 020

Melconian, S. (2012). Elementos de Máquinas. São Paulo: Èrica Ltda.

Miranda, M. M. (2012). Fator de emissão de gases de efeito estufa da geração de energia elétrica no Brasil: Implicações da aplicação da Avaliação do Ciclo de Vida (Master's thesis, Escola de Engenharia de São Carlos da Universidade de São Paulo).

Monahan, J., \& Powell, J. C. (2011). A comparison of the energy and carbon implications of new systems of energy provision in new build housing in the UK. Energy Policy, 39(1), 290-298. https://doi.org/10.1016/ j.enpol.2010.09.041

Moro, N., \& Auras, A. P. (2007). Professos de Fabricação-Fundição Florianópolis. Retrieved from http://norbertocefetsc.pro.br/downloads/fundicao.pdf

Oliveira, J. G. S. M. (2009). Materiais usados na construção de motores elétricos. Porto Alegre: PUC.

Parizotto, R. R., Siqueira, J. A. C., \& Nogueira, C. E. C. (2014). Instalação e avaliação de um sistema de bombeamento d'água com aerogerador de pequeno porte para propriedades rurais, na cidade de Cascavel-PR (Master's thesis, Universidade Estadual do Oeste do Paraná). Retrieved from http://tede.unioeste.br:8080/tede/handle/tede/783

Pick, E., \& Wagner, H. J. (2002). Cumulative Energy Demand (CED) and Energy Yield Ratio for Wind Energy Converters (p. 5). Proceedings: World Renewable Energy Congress VII, Cologne.

Savino, M. M., Manzini, R., Selva, V. D., \& Accorsi, R. (2017). A new model for environmental and economic evaluation of renewable energy systems: The case of wind turbines. Applied Energy, 189, 739-752. https://doi.org/10.1016/j.apenergy.2016.11.124

Schnöll, H. P., Brunner, H., Michael, Z., \& Hirz, M. (2015). CO 2 Reduction Potential of CFRP-Bodywork Concepts Considering Production and In-Use Phase. Conference: MOTSP 2015-International Conference Management of Technology_-Step to Sustainable Production, Brela, Croatia.

Schober, A., Kittel, C., Baumgartner, R. J., \& Füllsack, M. (2018). Identifying dominant topics appearing in the Journal of Cleaner Production. Journal of Cleaner Production, 190, 160-168. https://doi.org/10.1016/ j.jclepro.2018.04.124

Silva, V. G., \& Silva, M. G. (2015). Seleção de materiais e edifícios de alto desempenho ambiental. In J. C. S. Gonçalves, \& K. N. Bode (Eds.), Edificio ambiental (pp. 129-151). São Paulo: Oficina de Textos.

Song, Y. S., Youn, J. R., \& Gutowski, T. G. (2009). Life cycle energy analysis of fiber-reinforced composites. Composites Part A: Applied Science and Manufacturing, 40(8), 1257-1265. https://doi.org/10.1016/ j.compositesa.2009.05.020

Sposto, R. M., Caldas, L. R., \& Neto, A. C. N. (2016). Energia Incorporada e Emissões de $\mathrm{CO}_{2}$ de Fachadas de Light Steel Framing no Brasil. Oculum Ensaios, 13(1), 163-82. https://doi.org/10.24220/2318-0919v13 n1a2773

Tavares, S. F. \& Lamberts, R. (2008). $\mathrm{CO}_{2}$ embutido em edificações residenciais brasileiras. XII Encontro Nacional de Tecnologia do Ambiente Construído, Fortaleza, Brazil.

Tremeac, B. \& Meunier, F. (2009). Life cycle analysis of 4.5 MW and $250 \mathrm{~W}$ wind turbines. Renewable and Sustainable Energy Reviews, 13(8), 2104-2110. https://doi.org/10.1016/j.rser.2009.01.001

Venkatarama Reddy, B. V., \& Jagadish, K. S. (2003). Embodied energy of common and alternative building materials and technologies. Energy and Buildings, 35, 129-137. https://doi.org/10.1016/S0378-7788(01) 00141-4

Vestas Wind Systems. (2006). Life-Cycle Assessment of Offshore and Onshore Sited Wind Power Plants Based on Vestas V90-3.0 MW Turbines. Denmark. Retrieved from https://www.vestas.com/ /media/vestas/ about/sustainability/pdfs/lca_v90_june_2006.ashx

Wang, W., \& Teah, H.-Y. (2017). Life cycle assessment of small-scale horizontal axis wind turbines in Taiwan. Journal of Cleaner Production, 141, 492-501. https://doi.org/10.1016/j.jclepro.2016.09.128 


\section{Copyrights}

Copyright for this article is retained by the author(s), with first publication rights granted to the journal.

This is an open-access article distributed under the terms and conditions of the Creative Commons Attribution license (http://creativecommons.org/licenses/by/4.0/). 